\title{
HOW TO ASK QUESTIONS ABOUT ART AND THEOLOGY? THE EXAMPLE OF PAUL TILLICH
}

The first formulations in the field of theology of culture by Paul Tillich, one of the most important theologians of the $20^{\text {th }}$ century, date from the 1920s, when a very different cultural situation existed in an economic, political and cultural sense. In fact, the early years of his life was spent in the $19^{\text {th }}$ century (born on 20 August 1886 in Starzeddel, which was part of Germany at the time, but is now in Poland). Moreover, if we consider that fact that the August 1, 1914 (the beginning of World War I) is often the date used to mark the end of that century, the so-called cultural distance is perhaps even greater.

On the one hand, we have the relatively peaceful period of the later $19^{\text {th }}$ century, its humanist values, romantic philosophies, important scientific discoveries, and on the other, the $20^{\text {th }}$ century with its brutal carnages and emergence of brutal political systems in Europe. On the one hand, there is a longing for stability and on the other hand, there are revolutions, the severing of cultural traditions, scientific-technological progress, etc. Friedrich Wilhelm Joseph von Schelling (1775-1854) is considered to have exerted the greatest philosophical influence on Paul Tillich - the latter writes about von Schelling in both his dissertations. Proceeding from the works by Schelling, Tillich started to development his philosophy of Christian existentialism. Another great influence was theologian Martin Kähler (1835-1912), who emphasised the need to reduce the difference and distance between ecclesiastical beliefs, on one 
side, and reason and experience on the other. For Tillich, the role of translator and interpreter between cultural experiences and theology remained significant. For him, like for the rest of his generation, the greatest existential shock was World War I with its overwhelming suffering and victims. Tillich participated in the war as a chaplain between 1914 and 1918. After World War I, he dove into the bohemian life in Berlin, where experimentation and creativity characterised the art and politics. However, as a bohemian, he actively developed a cultural and religious philosophy that was sensitive to social justice and contrasted with the policies of the Weimar Republic.

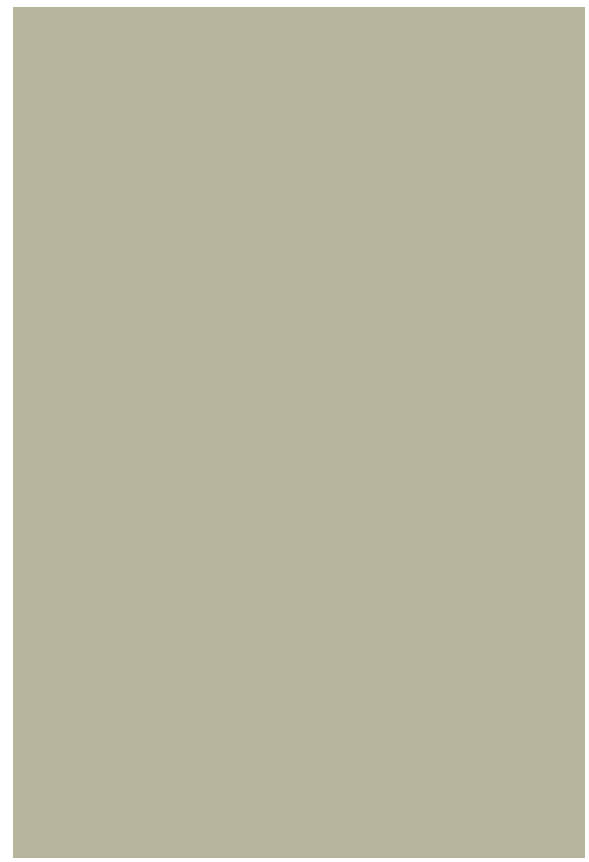

Fig. 1. Bust of Paul Johannes Tillich by James Rosati in New Harmony, Indiana, U.S.A. The central method of this "religious socialism" was cultural theology. Paul Tillich was both a cultural theologian and church theologian (his father was a leading Lutheran cleric too), thereby risking being alienated by both the secular culture and the church. His first public lecture in Berlin was called "On the Idea of a Culture of Theology" and culture remained a central concept in his theology. Tillich was ordained and worked briefly as a curate, but his career was mainly connected with academia, involving theology and religious research and he worked on faculties of philosophy at various universities.

In 1933, Tillich was dismissed from his position on the Faculty of Philosophy at the University of Frankfurt, and it soon became clear that he would have to escape from Hitler's Germany. Tillich was closely associated with the social scientists of the so-called Frankfurt School (Theodor Adorno, Walter Benjamin, Erich Fromm and others). With the help of friends in the U.S., he obtained a position in New York, and in the autumn of 1933, at the age of 47, Tillich started over in a strange language and 
cultural environment. During the next fifteen years, Tillich was relatively unknown (except in narrow theological circles) and few of his works were available in English. However, "The Shaking of Foundations" ${ }^{11}$, his collection of sermons published in 1948, became a bestseller. When volume one of his "Systematic Theology"2 was published he was already something of an intellectual superstar in the U.S., whose ideas were discussed in churches and academia. His last appointment was at the University of Chicago. Paul Tillich died in $1965^{3}$.

\section{TILLICH "ON THE BOUNDARY"}

Paul Tillich is one of the few theologians that non-religious people can relate to and, in the $20^{\text {th }}$ century, he was perhaps the greatest theologian who could serve as an intermediary between various cultural phenomena (art, sciences, and philosophy). Tillich's train of thought - although extremely systematic - did not create stifling totalitarian systems, but provided opportunities. Thus, he is a religious thinker that is comprehensible to philosophers, for Catholics he is the most catholic of Protestants, and his works have inspired sociologists, art critics, psychologists and many others. His originality may consist of the fact that his revealed a significant common ground shared by many aspects of life/culture and did so philosophically (i.e. based on culture), while remaining a theologian. He is always "on the boundary" as he has described in his book "On the Boundary". ${ }^{4}$ However, the boundary-situation does not mean Tillich saw himself as standing on a line that he did not dare or could not cross. Quite the opposite, in Tillich's case, being on the boundary meant being deeply rooted on both sides of the boundary, of having the ability to start a dialogue with the other side from the centre of both sides. Unlike many philosophers, he brings a religious or theological interpretation to culture, and unlike many theologians, gives religion a philosophical interpretation. This ability to mediate gives his ideas special relevancy, an almost universal scope of application.

\footnotetext{
1 Paul Tillich, The Shaking of Foundations (New York: C. Scribner's, 1948)

2 Paul Tillich, Systematic Theology, Volume 1 (The University of Chicago Press, 1951)

3 David H Kelsey, "Paul Tillich", The Modern Theologians. An Introduction to Christian Theology in the Twentieth Century, ed. David F Ford (Cambridge, MA, Oxford, UK: Blackwell Publishers, 1997), 87-102.

4 Paul Tillich, On the Boundary: An Autobiographical Sketch (New York: Charles Scribner's Sons, 1966 [1936]). This book introduced Tillich to the American readers.
} 
How is this possible? The precondition is Tillich's belief that God is the basis of man's ultimate reality, of reality itself. Or the opposite, that one and the same depth-content ultimately forms the basis of all culture and of religion. This depth-content is made visible by the religious examination of culture (cultural theology) and the proper cultural (i.e. philosophical) examination of religion reveals the basis of religion. Therefore, cultural phenomena (states, art and science communities, churches and other institutions) and religious phenomena are closely related. Culture is a coherent and valuable finitude, and its infinite basis is the basis for everything. Culture is religious, and the eternal question therein is, what is the ultimate concern of human existence? This question provides culture with an opportunity for self-transcendence. Religious art reveals the unconditional truth. Religion is the substance of culture (the depth-content that contains the meaning of culture) and culture is the form of religion (formal structures that enable meaning to be expressed, e.g. art, science, morality, the legal system) - this was Tillich's famous maxim about the relationship between religion and culture ${ }^{5}$.

This definition precludes the dualism of religion and culture. Every religious act, in institutionalised religions as well as the most private stirring of the soul, is given form by culture. Therefore, attention should be paid to concrete and specific cultural situations. Since religion is directed toward the absolute, it cannot simply be a field within culture or alongside it. However, in the same way, culture cannot be subordinated to religion - it would thereby lose itself. Culture determines the form in which it expresses its content, even when culture expresses absolute, religious content. Culture must not allow truth and justice to be sacrificed in the name of the religious absolute. No culture or cultural form is capable of totally and directly expressing the absolute, but culture can strive to perceive the human existence in its ultimate, relative and autonomous forms. Tillich has said that God often speaks to the church more directly than through the representatives of the church outside the church, even through those who are opposed to religion and Christianity. Cultural, social and political movements can mediate new visions to the church and society, and when this happens, God is

5 Tillich, On the Boundary, 69-70. Paul Tillich, Theology of Culture, ed. Robert C Kimball (London, New York: Oxford University Press, 1964), 42. 
speaking through those cultural, political or social movements. ${ }^{6}$ Tillich considered Expressionist art especially important, seeing therein the "denunciation" of a mere fragmented existence and the revelation of a paradoxical and almost mystical perception, in which tension was created between dread, the world, and the affirmation of the unity of everything that exists. In this, he saw the breakdown of petty bourgeois ethics in the name of the ethics of a greater and more all-encompassing love.

As soon as religion is discussed, critics from all camps can be expected to react. The more conservative theologians asked Tillich whether he thought religion was an element that creates or one that is created by the human spirit, or does he see it as a gift of divine manifestation. If one answers that religion is an aspect of a person's spiritual life, then some theologians will turn their back on this. Secular scientists might ask whether religion is to be viewed as a permanent trait of the human spirit, or something created by psychological and sociological circumstances. If one answers that religion is a necessary aspect of a person's spiritual life, then secular scientists too will turn their back on this, but in the opposite direction than the theologians.

Theologians (like Karl Barth and his followers) who do not like the answer that religion is an element of a person's spiritual life, justify their claim that meaning of religion is expressed in the fact that people accept something that does not come from them, which has been given to them and which they may be critical of. ${ }^{7}$ There is also a difference between Catholic and Protestant attitudes. Catholicism is based on the holy and the profane, while Protestantism does not postulate any separate spheres. No individuals, scriptures, communities, institutions or activities are in their essence holy and none in their essence profane. The profane may contain holiness and the holy does not stop being profane. Priests are secular beings and secular being can become priests, just like any other things. Tillich noted, "the unconditional nature of religion becomes far more manifest if it breaks out from within the secular, disrupting and transforming it." ${ }^{\prime 8}$ Religion becomes blasphemous when some insti-

6 Paul Tillich, Perspectives on 19th and 20th Century Protestant Theology. Ed. By Carl E. Braaten (New York: Harper and Row, 1967), 236.

7 Hans W. Frei, Types of Christian Theology. Ed. By George Hunsinfer and William C. Placher (New Haven and London: Yale University Press, 1992), 38

8 Tillich, On the Boundary, 72. 
tutions or individuals are considered to be in essence holy and faith is considered to be an inseparable requirement of some vocation.

Tillich has repeatedly said that existentialism was a great boon for theology. He defined three meanings for existentialism: existentialism as an element in all kinds of significant thinking; existentialism as a revolt against some elements of industrialised society in the $19^{\text {th }}$ century; and existentialism as a mirror reflecting the situation of sensitive $20^{\text {th }}$-century people. Tillich said that all $20^{\text {th }}$-century art is in essence existentialist. Great existentialist art is born when artists dare to "bear the burden" of anxiety and meaninglessness, when they express the oppression of their era, the destructive trends in culture, the fear of not being and they relate prophetically and creatively to the present day. This kind of art is also important and meaningful for theology.

Existentialism as a universal element of thinking alludes to an attempt to describe a person's existence and conflicts therein, the source of those conflicts and the hope of overcoming them. In this sense, he also considers Plato to be a thinker with existentialist traits. Existentialist elements can also be found in early Christian theology, e.g. in the case of St. Augustine, as well as in the Middle Ages, and in Protestantism. ${ }^{9}$ Whenever man's predicament is described poetically, philosophically or with the help of some art form, existentialist elements exist.

The second meaning of existentialism is as a revolt. This got its start during the development of the industrialised society in the $17^{\text {th }}$ century. Blaise Pascal was one of the distinguished representatives who protested against the Newtonian world, in which man was just a small cog in the great machine. The revolt continued during the $19^{\text {th }}$ and $20^{\text {th }}$ centuries with Schelling, Kierkegaard, Engels, Feuerbach, Nietzsche, Bergson and Whitehead - all those who protested against man being viewed simply as a thing. In the $20^{\text {th }}$ century, this feeling started to become increasingly universal. The aforementioned philosophers were forerunners, lonely, often desperate prophets. In the $20^{\text {th }}$ century, the revolt became

9 According to Tillich, Plato was the first classical philosopher who had many existentialist elements in his thinking, especially in those instances where he employs mythology. St. Augustine is existentialist so far as he is describing the estrangement of humans from their true essence. Paul Tillich, „Existentialist Aspects of Modern Art“, Christianity and the Existentialists, edited by Carl Michalson (New York: Charles Scribner's Sons, 1956), 128-146. http://www.religion-online.org/showarticle. asp?title $=1568$ (viewed 01.06.2014) 
universal, and it was expressed by poets, writers, culture researchers, sociologists, as well as artists. ${ }^{10}$

Tillich's definition of religion was broader than that of many others. He said religion means believing that something is an ultimate concern - the question of whether to be or not to be, and the symbols with which to answer this question. This means that religion is revealed when the question of people, the world, culture and nature are taken extremely seriously. In the narrower sense, religion is, of course, a set of symbols related to a god or gods, symbolic references to the activities of these gods, and the rituals and educational formulations about the relations of these gods with people and the world. In the narrower sense, religion refers to a belief in God and the intellectual and practical conclusions based thereon. When speaking about religion and art, one must differentiate between these two understandings of religion.

\section{RELIGION AND SYMBOLS}

When we think about religious art, we should first consider the works that utilise religious symbols, such as pictures of Jesus or the saints; and, of course, in the case of other religions, their important symbols. This is one way to look at religious art. However, based on a broader definition of religion, one can see an expression of the ultimate concern in all kinds of art.

1. A symbol "points beyond itself."

2. A symbol participates in the meaning and power of what it symbolises. A symbol is iconic for that to which it refers.

3. A symbol reveals "the meaning of something which cannot be approached in any other way."

4. A symbol "opens our soul to dimensions and elements that correspond to the dimensions and elements of reality".

Religion needs symbols, because religion deals with ultimate concern and "the true ultimate concern transcends the realm of finite reality infinitely. Therefore, no finite reality can express it directly and properly."11 This is important because it explains why we need symbols to speak about God and the deepest things in life. If we speak about reli-

10 Ibid

11 Paul Tillich, Dynamics of Faith (New York: Harper \& Brothers, 1957), 44. 
gion without the help of symbols, we distort religion and say nothing about its meaning. All creative arts require symbols in order to express that which cannot be grasped by scientific descriptions.

A symbol is not a concept or idea. Ideas help us to talk about knowledge, but with the help of symbols, we arrive at actual incarnation. Through symbols, it is possible to participate in the basis of being. For example, a statue of Buddha or an icon can simply be an aesthetic object and then the viewer is in a secular position. But they can also become symbols; and then the statue of Buddha refers to the Buddhist nature of all things; and the icon to the basis of being (or God). A participatory relationship exists not only with religious symbols, for example, the state flag of any society symbolises a political relationship and it is treated in a special way (state buildings, coats of arms, and people who carry out certain functions, like presidents or kings, can also be symbolic). The symbol participates in the power and meaning of the thing being symbolised - here there is clear difference between a symbol and a sign or mark.

Secondly, a symbol overturns the main dualisms that we utilise for viewing ourselves, and our relationship with the world and it offers alternatives. Symbols cannot be approached literally. A symbol reveals the meaning of something and we cannot arrive at this meaning by any other means.

Thirdly, a symbol can interpret the situation in the given society or culture. If we do not have suitable symbols, the situation remains impenetrable for us. Tillich also says that symbols are like living beings - they are born and they die. Symbols cannot be created artificially and if a symbol does not work, it dies.

Tillich was a systematic thinker and he discussed art with the help of typology and categories. The simplest of Tillich's typologies is comprised of three elements: naturalism, idealism and expressionism. In his second typology, Tillich used four types, depending on whether the content and style is religious or non-religious. In his third typology, style is coordinated by the five elements (imitative, subjective, idealistic, realistic and expressive) with religious types. In the fourth, there are six types: impressionism and realism (in both, form dominates); romanticism and expressionism (in both, meaning dominates); idealism and classicism, 
in which Tillich saw a balance between form and content $t^{12}$. However, it is also true that typologies are always relatively easy to attack, because they are ideal forms for which contrary examples can always be found. In his later years, Tillich tried to answer his critics and abandoned the use of typologies in favour of dimensions and key traits. In any case, the expressionist style remained closest to his heart. He said that that the expressive style conveys the symbol of the cross, but not the Resurrection. In this approach, he subordinated the affirmative and confirmative roles of art to the breakdown of all life forms, and the prophetic role was expressed in the depiction of that rupture (not in harmony).

\section{ART AND RELIGION - THE FOUR LEVELS}

Below, I introduce the four levels of the relationships between art and religion ${ }^{13}$ described by Tillich, because this may help to orientate between religious and non-religious art today.

1. Non-religious style and non-religious content. The level is a style in which ultimate concern is only expressed indirectly. This is usually defined as secular art because it has no religious content and does not use any religious symbols. The works of art depict everyday life, landscapes, people, various events, etc. Tillich offers Jan Steen's "The World Upside Down" (ca 1663) as an example. What does Tillich think this painting conveys? He says that, through unrestricted vitality, in which the self-affirmation of life becomes almost ecstatic, the power and basis of being becomes visible. One could say that this has nothing to do with religion, but Tillich does not agree. Yet, it is indirectly religious; the painting does not have a religious style; nor does it have a completely secular style or any religious content. Nevertheless - and this is a Protestant principle - God is present in secular existence as much as he is present in sacred existence. Neither is closer to God. But the power of being is made visible. Tillich offers Peter Paul Rubens" "Return of the Prodigal Son" (1618) as an example. Tillich has always been inter-

12 Robert P. Scharlemann, “The Religious Interpretation of Art”, The Thought of Paul Tillich, ed. James Luther Adams, Wilhelm Pauck, and Roger Lincoln Shinn (San Francisco: Harper \& Row, 1985), 173. 13 Paul Tillich, Christianity and the Existentialists, edited by Carl Michalson, (New York: Scribner's Sons, 1956), 128-146. 
ested philosophically in Rubens' landscapes - they provide the viewer with a dynamic sense of the cosmos; the viewer becomes a part of the cosmic whole. The scenes of everyday life become symbols that reveal reality in a way that would not be accessible without symbols.

2. Religious style and non-religious content: the existentialist level. There are no holy scenes, but there is style, and this style is the form that expresses the meaning of the given period. If you want to know what the self-interpretation of ultimate concern is in a given historical period, you must ask which style characterises the art of this period. Style becomes visible as an over-all form comprised of the particular forms of each artist and each school, and which is the sub-conscious self-interpretation of the given period and this period's answer to the most important existential questions. The characteristic of this style is that something is always breaking through from the depths to the surface. Whenever this happens, we have a style that is religious in nature even if there is no religious content depicted. Modern existentialism in the visual arts starts with Paul Cézanne (1839-1905) in France. Tillich thinks that modern art had transformed all of reality into forms of still life, which are atomistic, disrupted. Our existence is no longer depicted with the help of idealistic organic forms. The colourful world of the Impressionists and the beautifying pictures of the idealists are reduced to cubic forms. But, the artists would not say that these forms are unorganic, but rather that unorganic forms are the fundamental elements of life. Thus, in an unorganic idi$\mathrm{om}$, the power of being can become very visible. Expressionism, surrealism, cubism, futurism, are all an attempt to look into the depths of reality. Or, for instance, Vincent van Gogh's “The Night Café" (1888), in which one lonely man in the middle of an array of beautiful colours represents the horror of emptiness. Or the horror and shock of Edvard Munch's paintings, which cannot be grasped by the rational mind. Or Pablo Picasso's works, of which "Guernica" (a small town in Northern Spain where the Fascist countries, Germany and Italy, helped the Fascist Spaniards to overthrown the Loyalist government, because it was leftist) was most important for Tillich. Tillich considered "Guernica" (1937) to be the most Protestant $20^{\text {th }}$-century painting - it lays bare the 
Fig. 2. Heinrich Hoffman, "Christ and the Rich Young Ruler". 1889 (Riverside Church, New York).

human situation and predicts the imminent onset of World War II. If Protestantism means that we do not need to beautify or cover up anything, but must look into its depths of estrangement, suspicion, emptiness and despair of the human situation, then this is one of the most powerful religious pictures, although it has no religious content. A style can be deeply religious without containing any traditional religious symbols.

In Germany and the U.S. in the late $19^{\text {th }}$ century, a large number of sentimental religious paintings were created - one example is the oeuvre of Heinrich Hoffman (1824-1911). Tillich thought that Hoffman's mawkish paintings of Jesus (for instance, in Riverside Church in New York) did not express anything about God or reality, although thousands or even millions of such pictures have been reproduced.

Tillich has commented on Marc Chagall's painting "Time is a River without Banks" (1930-39) as well. He said that it could not 
Fig. 3. Carl Timoleon von Neff (1804-1877), "The Descent from the Cross". Undated, after Rembrandt Harmensz van Rijn (1606-1669). Oil, canvas (AME). 
be understood from a naturalistic point of view. The painting is strongly symbolistic, and yet everyone feels the metaphysics of time passing that is behind it. In Chagall's paintings, "Lovers and The Birthday", Tillich greatly appreciates the element of fantasy; and how possible natural relationships are upset. The lover comes from the clouds because in his beloved's imagination he is something much greater than he is in reality. According to Tillich, surrealist Giorgio de Chirico's "Toys of a Prince (Evil Genius of a King)" (1915) is also an existentialist painting. The elements of reality are brought into a new context, which has nothing to do with reality. Chirico's painting may depict infinite space into which we look; the blinding power of the sun or loneliness. Tillich calls these works the carriers of a religious style "religious" in the broader sense), although the paintings he is talking about have not religious content. Why a religious style? Because this style poses a religious question in a radical way and has the power and courage to view the situation from where this question develops, from the human predicament. In earlier centuries, there were painters who did the same. Some examples are the demonic pictures created by Francisco Goya, Pieter Brueghel or Hieronymus Bosch, where elements of the psychological, as well as the natural, reality are brought into the picture without any naturalistic connection with each other. We can talk of existentialism in the case of all such works: the essential categories of time, space, causality, and substance have lost their ultimate power. These categories give meaning to our world; with their help, we can understand things. We can understand that one thing follows another, one causes another, and each has its space and its time and so on. However all this is no longer important, Tillich explains. Humankind no longer feel at home in this world. The categories have lost their embracing and overwhelming power. There is no safety or sense of security in the world.

In the Psalm 90 of the Old Testament and the Book of Job, Chapter 7, it is said that man's "place does not know him anymore." These are profound words. In existential pictures, these things are displaced. Displaced persons are a symbol of our time, and displaced souls, domestic exiles, can be found in all countries, not to mention the millions of war and economic refugees. This 
Fig. 4. Olga Terri, "Kiss of Judas". Oil plywood, 1945 (AME). 
large-scale displacement of our existence is expressed in these pictures. All this displacement does not provide a positive answer or programme for our existence. When Tillich spoke about Christian existentialists, he said that they are existentialists insofar as they ask the questions and reveal the estrangement, finitude, and meaninglessness. They are Christian insofar as they answer these questions as Christians, but not as existentialists. For this reason, Tillich does not believe that the distinction between atheistic and theistic existentialism makes any sense. Nevertheless, since existentialism describes the human situation, as such, it is a decisive element in present-day religious thinking.

3. Non-religious style and religious content. For instance, pictures of Christ and the saints, and in art history, the non-religious style of the High Renaissance that deals with religious content. Here Tillich cites the example of Raphael's "Alba Madonna" (1510). It is religious neither in substance nor in style. This is one of the differences between Raphael and Chirico. In the Chirico, the disruptiveness of reality is visible, while Raphael depicts a harmonious humanity, which of course, is indirectly religious, but is not religious in style. Or take the French artist Jean Fouquet's "Madonna and Child" (Melun diptych, ca.1452). Fouquet's Madonna is a lady of the court with a questionable reputation. We know who she is, and yet she is depicted as the Madonna. Here the religious symbol of the Madonna and Child is not combined with a religious style, but is reduced to the mother-child relationship of a lady of the court. Tillich mentions a few times also Peter Paul Rubens' painting "Madonna and Child" (he does not specify which painting) where a beautiful lady and a beautiful child are depicted. Wonderful to look at, but no one would think of this Madonna as the mother of God. This shows that religious content alone does not make a religious picture. An untold number of such pictures can be seen in private collections or in various congregational and church publications, as well as in churches and the offices of pastors and priests, etc. They have religious content but no religious style. In this sense, they are dangerously irreligious, and Tillich believes, they are something that should be combated. 
On the fourth level, religious style and religious content are united. This is art, which, in the most concrete sense, can be called religious art. It can be used for liturgical purposes or for private devotion. In it, style and content agree. But, it is this art that provokes Tillich to ask, "Is it possible today?"

4. Religious style, religious content and impact. Religious content finds expression in religious form. This form is generally called expressionistic because in this form the depth-content breaks through the surface; or in other words, it is a form of artistic honesty. Such pictures existed long before modern times. Tillich provides the example of Mathias Grünewald's famous "Crucifixion" on the Isenheim Altar (1512-1516). Tillich believed that it is the greatest picture ever painted in the German cultural space, and the greatest specifically Protestant painting. He considered El Greco's "Crucifixion" (1596-1600), to be an expression of the aesthetic form of the Catholic counter-Reformation, in which the unnatural form of the body expresses the artist's ecstatic self-elevation towards the Divine through asceticism and self-destruction.

Grünewald work can also be compared to Graham Sutherland's (1903-1980) "Crucifixion" (1946). According to Tillich, this contemporary work is very similar in form to Grünewald's painting, but has all the elements of disrupted style, which modern art has created.

In this context, Tillich asks a question that he cannot answer: Is this fourth level possible in art today? Is it possible to use these elements of expressionist visual art to deal with the traditional symbols of Christianity? In Sutherland's case, he thinks that it may be possible. In the case of some others, Tillich is not sure. For instance, in the case of Emil Nölde (1867-1956), a German expressionist, Tillich finds that Nölde was not able to renew the Christian symbols with the help of modern art (i.e. from the early $20^{\text {th }}$ century). Nevertheless, I believe that Emil Nölde's "Christ and the Children" from 1910 presents a very serious existential and religious challenge. In any case, the question remains, can modern humans answer the question that existentialism poses?

If we replace the existential expression of the situation with idealistic naturalism, beautifying realism, then art covers up reality. The artists that can reveal situations have a prophetic function. 


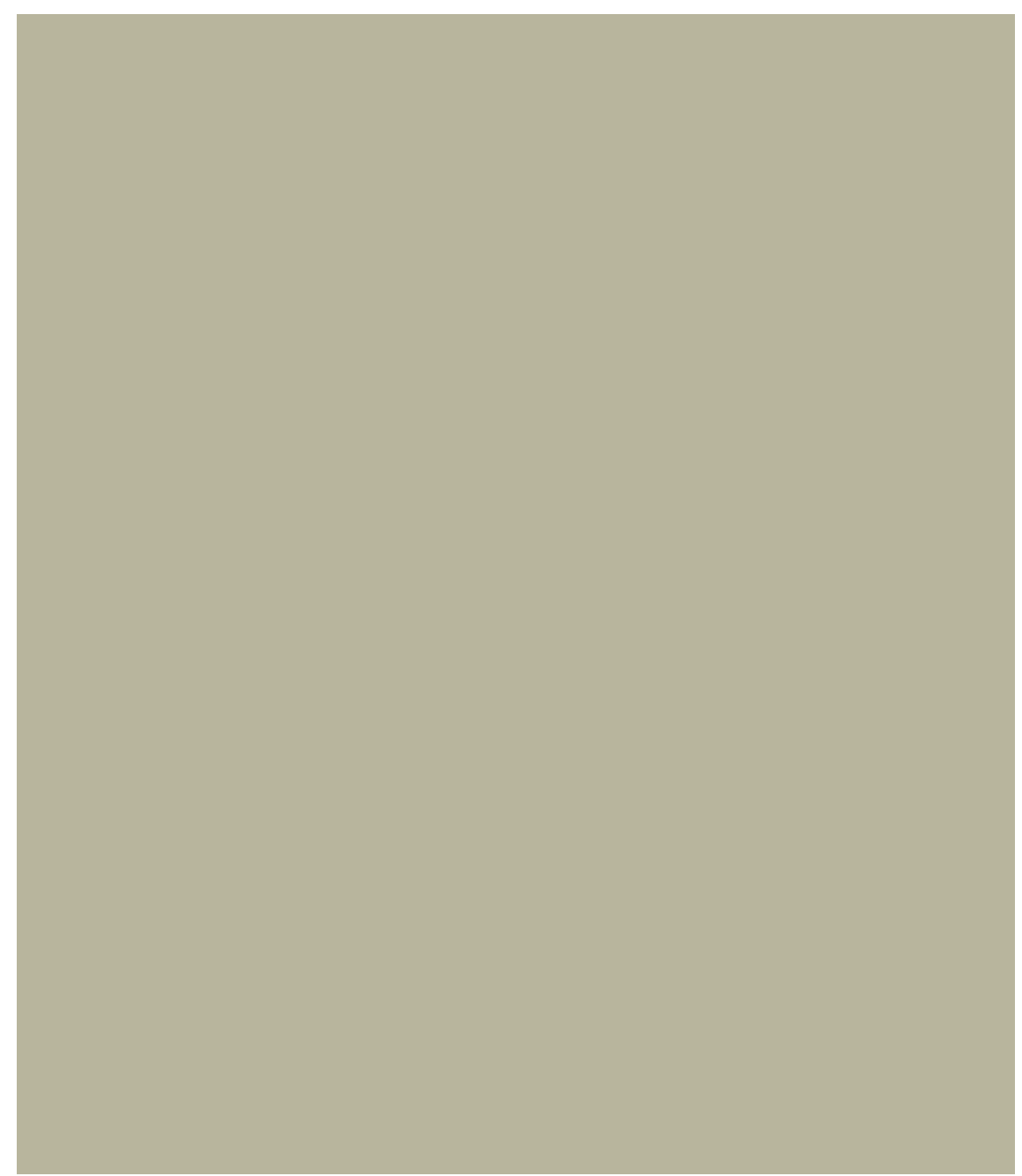

Fig. 5. Vive Tolli, "Salome". Coloured chalk, felt-tip pen, collage paper. 1960s. (AME).

This does not mean that that one must like their work - the ancient prophets were also unpopular. There are moments in the lives of individuals and societies, when some things can no longer be covered up or concealed, and if attempts are made to do this, it is at the cost of honesty and the bill that will have to paid includes fanaticism, the suppression of the elements of truth and self-destruction. We must be able to face reality and existentialist 
artists help us to do so. Tillich recalls that Hitler collected many existentialist works of art into a museum of degenerate art, and these works were "guilty" of excessive pessimism and negativity; and after the war, these same works were considered the greatest works of $20^{\text {th }}$-century art.

And how did Tillich connect all this to the church? Most of the churches, in a petit bourgeois fashion, opposed contemporary art and existentialism in the broader sense. The churches believed that they had all the answers. But by believing that they had all the answers, they often deprived the answers of any meaning. These answers were no longer understood, because the questions were no longer understood, and this was the mistake made by the churches. They did not do what the existentialist artists did. They did not ask the questions over again about the depth of the experience related to despair, as they should have.

The churches did not ask this question and therefore all the answers, the answers that are in the Christian creeds, became empty. No one knew what to do because the questions were no longer alive in the same way they had been when the creed developed. Therefore, Tillich thought that existentialist art has a infinite religious function, both in the visual arts and in other forms - namely to rediscover the fundamental questions for which Christian symbols provide an answer, but in a form that is comprehensible in our time. Then these symbols will become understandable again ${ }^{14}$.

In 1965, Tillich gave his last known lecture on art at the University of California, Santa Barbara ${ }^{15}$. He confirmed that he was speaking, not as an expert on art, but as an art lover who approaches art as a theologian and philosopher. In the lecture, he spoke again about the religious dimension as one of depth and ultimate concern and that this is greater than just a narrowly institutional religion. Tillich observed that during the last few decades, and actually, since the mid- $17^{\text {th }}$ century, religion in the narrow sense has inspired artists amazingly little. However, the

14 Paul Tillich, „Existentialist Aspects of Modern Art“, Christianity and the Existentialists, edited by Carl Michalson (New York: Charles Scribner's Sons, 1956), 128-146. Vt ka http://www.religiononline.org/showarticle.asp?title=1568 (viewed 01.06.2014)

15 Paul Tillich, "Religious Dimensions of Contemporary Art," On Art and Architecture, ed. John Dillenberger, in collaboration with Jane Dillenberger (New York: Crossroad, 1987), 171-187. 


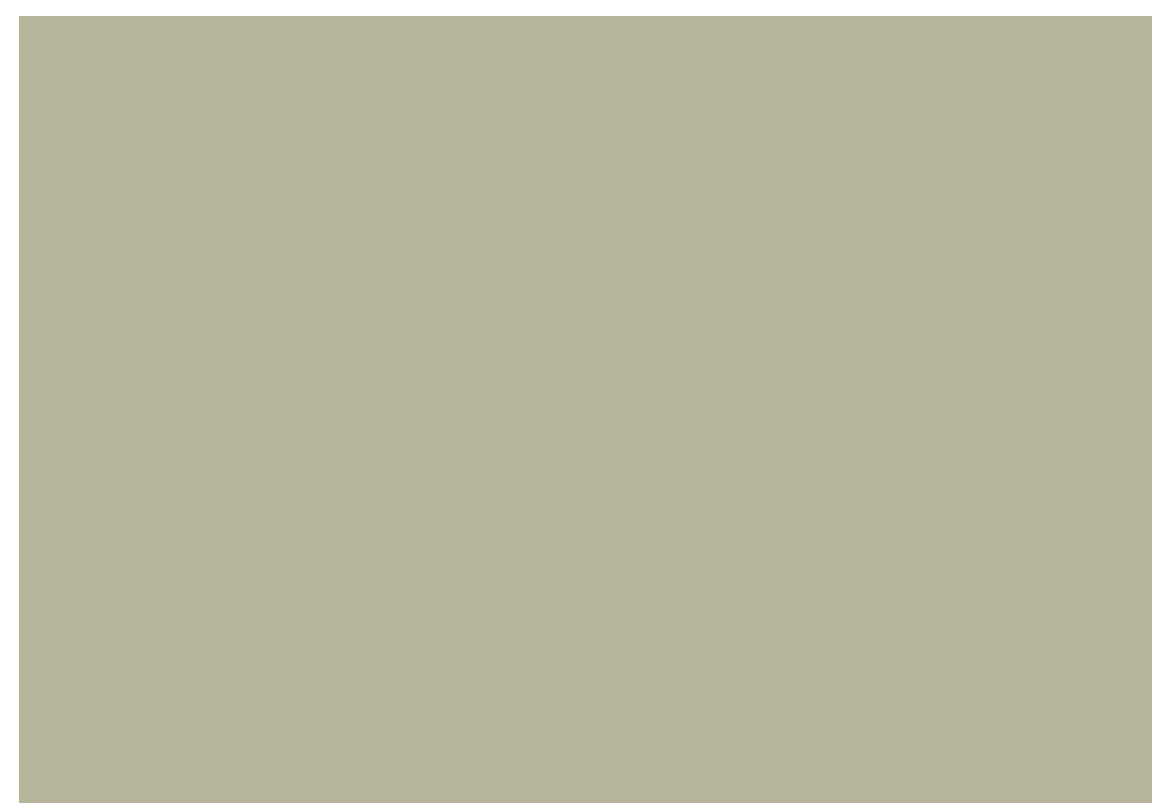

Fig. 6. Eduard Wiiralt, "The Last Supper". Lithography, paper 1925, (AME).

secularised perception of life does not mean that religion in the broader sense has disappeared. According to Tillich, art is the expression of encounters with reality. Religiosity is expressed not by content or the subject, but by style. Style develops from a specific encounter with reality and it defines the content of the subject. Tillich pointed out the differences between the naturalistic, idealistic and expressionistic styles. He considered the expressionistic style to be predominant in religious art because, by nature, it is close to the religious experience that shapes and transforms the world by shaking its very foundations. In this lecture, Tillich also tried to deal with the newest art, which he saw as a revolt against conventional elements. One of his examples was Willem De Kooning's "Woman I" (1950-52), in which the artist returns to the human figure, but totally negates the idealistic or naturalistic canon. Tillich briefly also dealt with Pop and Op Art. What do these new styles mean from a religious standpoint? He said that expressionism has expended itself and it is not possible to return to it, because, reality is being experienced in new ways. Artists, if they are honest will show us this. This reality may be foreign, alienating or intimidating, and no clear boundaries may 
exist between art and non-art. At the same time, the so-called "death of Christ" theology developed which talked about God without God, and philosophy instead of dealing with wisdom, started expounding on logical and semantic calculations related to the meaning of life and categories of thinking. Yet, this is our situation and we cannot continue looking at the world as if no changes had occurred in the $20^{\text {th }}$ century and to continue painting (or philosophising or theologising) as people did in 1900. And thus, we have to consider that contemporary art is also an inexhaustible manifestation of the creative basis of reality - although the temporal distance maybe still too short for a final assessment.

\section{IN CONCLUSION}

Of the great theologians of the $20^{\text {th }}$ century, Paul Tillich was the only one who systematically dealt with various cultural phenomena (science, art and architecture, politics). He gave lectures about painting and architecture. It is also true that he had his favourites - but this should not be seen as criticism. Expressionist art was the art form that deeply influenced his thinking. However, even art historians usually do not possess equal competency in all the different styles, periods, or individual artists, and can be cursory or even downright wrong in their assessments when dealing with art forms or styles with which they are less familiar. Tillich was able to add new nuances to his approach to art right up until the end of his life, and more than anyone else, he made people aware that the arts reveal aspects of comprehension related to the richness of our experience, which would not be possible with art.

Tillich's theology of art is still useful and can be a point of departure for reflecting on the connections between art and religion, but Tillich himself would definitely have opposed viewing his analysis as the final word. That which Tillich began can and must be supplemented - the existential situation of humans has changed during the last fifty years; nature, technology, language, and the religious experience and the ways of expressing this experience have changed too. And if Tillich paid special attention to art that expressed the depth of desperation, oppression and alienation, then there must definitely be artists who can establish a critical relationship with current techno-nature as well as cautiously express hope. Thus, for example, the Australian artist Patricia Piccinini 
ponders the theory of evolution in her work. How is change born, how do we know that someone in their new form or genetic structure is more suited to its environment; what are our relations with all the other forms in nature with whom we share our world. Can we love beings that we ourselves have created? Piccinini often depicts beings that actually do not exist, but still resemble existing species. The fantastic intersects with reality, imagination with knowledge, and the witnesses are often children or teenagers, who analytically and inquisitively - without fear or hatred - operate in this fantastic world. And this is very good.

Anne Kull: How to Ask Questions About Art and Theology? The Example of Paul Tillich

Keywords: Religion, Culture, Existentialism, Types of Relating Art and Religion

SUMMARY:

This presentation titled "How to Ask Questions in Art and Theology? The example of Paul Tillich" was intended as an introduction of Paul Tillich (1886-1965), one of the greatest theologians of the 20th century, for an audience of art historians to. Tillich was born in Germany, and as for many of his generation, the first great upheaval in his life was caused by World War I. Tillich participated in the war as a chaplain. In 1933, the Nazi authorities suspended him from his academic position and soon he had to flee Germany. His friends invited him to the U.S. where he worked at the Union Theological Seminary in New York City, after retirement, at Harvard University, and starting in 1962, at the University of Chicago. All his life he was concerned with the mediation of contemporary culture and Christianity. One of his favourite topics was art. Tillich was a very systematic thinker but his system was never totalitarian or oppressive - everybody could relate to his thinking. Tillich suggests that the human condition always raises fundamental questions, which human cultures express in various ways in the dominant styles of art. According to Tillich, existentialist elements exist in all thinking, but the second meaning of existentialism is as a revolt against the industrial so- 
ciety. In the 20th century, existentialism became a universal feeling. Art reveals some of the innermost motives of existentialism. Religion can be defined in the narrower sense, religion as a belief in the existence of a god, accompanied by intellectual and practical activities. But religion in the wider sense means being ultimately concerned. Based on this broad definition, Tillich differentiated the following four main ways of relating religion and art: 1) non-religious content and non-religious style; 2) non-religious content and religious style; 3) religious content and non-religious style; 4) religious content and religious style. He was always very critical of sentimental, beautifying naturalism and idealism and the taste of the petit bourgeoisie. He urged churches to search as seriously for the real questions of the present time as existentialist art did using artistic means. In this sense, he thought existentialist art has a tremendous religious function, namely, to rediscover the basic questions to which religious symbols can provide the answers. (As he was mainly discussing European and North-American art, the relevant religious symbols were Christian ones - at least during the 20th century). In his last lecture on art in 1965, he said that pure expressionism seems to have exhausted itself. It is impossible to return to the style of the 1900s after the extraordinarily rapid changes in societies, different academic disciplines and general experience of reality that had taken place. Thus, he also saw Pop and Op Art in a positive light, as honest artistic responses to those experiences. Better than any other theologian of his time Tillich knew that the visual arts, like the arts generally, provide with us facets of understanding that they alone cannot supply. Tillich's thoughts are not the last word on the topic of art and religion, but they are certainly a very good starting point for continuing to read the signs of the times with the help of various arts.

CV:

Anne Kull received her Ph.D. at the Lutheran School of Theology at Chicago. Since 2000 she has taught systematic theology at the University of Tartu, Estonia. Her main research area is contemporary culture and theology, particularly science, technology and religion. She is a member of the research group in religious studies at the Centre of Excellence in Cultural Theory and founder of the Collegium of Science and Religion at the University of Tartu. 